\title{
OCCURRENCE AND CHEMISTRY OF DIHYDROXYFUMARIC ACID
}

\author{
N. Secara, Gh. Duca, L. Vlad, F. Macaev* \\ Institute of Chemistry of the Academy of Sciences of Moldova, \\ 3 Academy str., MD-2028, Chisinau, Moldova \\ Tel+373-22-739-754, Fax+373-22-739-954,E-mail: flmacaev@cc.acad.md
}

Dedicated to academician Pavel F. Vlad on the occasion of his $75^{\text {th }}$ birthday

\begin{abstract}
The paper summarizes literature data on occurrence of dihydroxyfumaric acid and its role in biological
\end{abstract} systems, as well as its chemical properties.

Keywords: dihydroxyfumaric acid, fluorescent sensors, molecular clips, coordination polymers

\section{Introduction}

The role of many hydroxy acids, such as malic, lactic, glycolic, citric, tartaric, in living organisms and plant metabolism is generally recognized. The interest in plant metabolites as sources of biologically active compounds appeared a long time ago. One of the leaders, due to its potential, in the series of natural sources is the dihydroxyfumaric acid $\mathbf{1 .}$ It is clear that discovery of the relationship between structures and properties can conduct to successful development of new effective antioxidants, drugs etc. In this paper, we tried to systemize literature data based on occurrence of dihydroxyfumaric acid $\mathbf{1}$ in biological sources and synthetic transformations into target products, which should be convenient (from our point of view) for the chemists. This approach is presented in our review.

\section{Structure and occurrence of dihydroxyfumaric acid in biological systems}

Dihydroxyfumaric acid is $\mathbf{1}$ a dicarboxylic hydroxy acid, which is formed from tartaric acid via dehydrogenation or oxidation processes.

For the first time, it was chemically obtained in 1894 by Fenton, as a product of tartaric acid oxidation by hydrogen peroxide, in the presence of Fe(II) [1,2]. Dihydroxyfumaric acid has trans-and cis-isomers. The trans-isomer is called the dihydroxyfumaric acid, and the cis- isomer is called the dihydroxymaleic acid. Fenton suggested that the dihydroxyfumaric acid mainly exists in its cis- form, therefore in all scientific work before 1950's, the acid is referred to as dihydroxymaleic. At the beginning of the XXth century it was proved [3] that these forms are chemically identical, and in 1953 Hartree [4] showed that in crystalline form, as well as in solution, only the trans- isomer exists. Also, it should be mentioned that dihydroxyfumaric acid in solution exists in two tautomeric forms in equilibrium (Scheme 1):<smiles>CCC(O)C(=O)C(=O)O</smiles>

\section{Scheme 1}

In solution, $80 \%$ of the acid usually corresponds to the enolic group, and the other $20 \%$ - to the keto-group $[5]$.

Similarly to tartaric acid, dihydroxyfumaric acid (DHF) plays an important role in nature. The first proofs of its biological significance appeared in 1915 when Neuberg [6] observed that DHF was fermented by yeast. In 1938 Banga and Szent-Gyiirgyi [7] and Banga and Philippot [8] extracted an enzyme, which they called dihydroxyfumaric acid oxidase from plants; the oxidation product was later proved to be diketosuccinic acid. In 1940 Theorell also discovered an enzyme in some plants, which oxidized dihydroxyfumaric acid with oxygen uptake, and he proved that enzyme to be peroxidase.

It was shown that the active centers of dihydroxyfumaric acid oxidase and peroxidase are the coordination compounds of iron ad copper [9]. As it was previously said, these ferments catalyze the transformation of DHF into diketosuccinic acid 2.

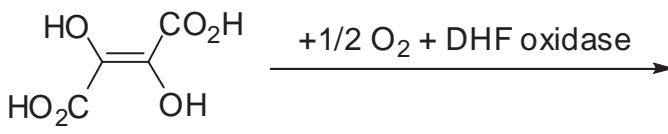

1<smiles>O=C(O)C(=O)C(=O)C(=O)O</smiles>

Scheme 2 
Therefore, it was suggested [9] that in the system oxygen + DHF-oxidase, the role of DHF is similar to that of ascorbic acid $\mathbf{3}$ in the ascorbate-oxidase system which afforded $\alpha$-diketone 4 (see Scheme 3).
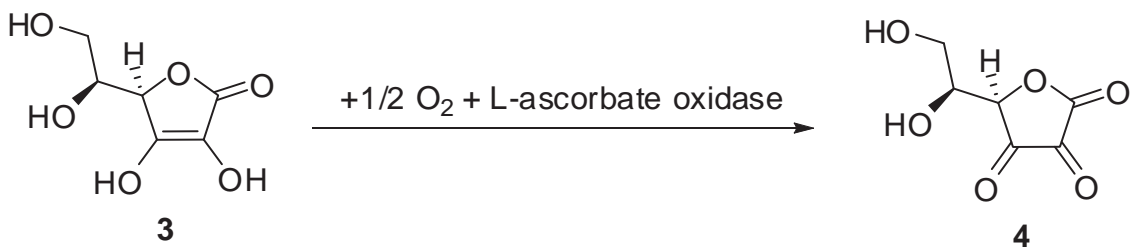

Scheme 3

It may be observed from these schemes that the dihydroxyfumaric acid bears some similarities with the ascorbic acid, and therefore, in biological oxidation, it may play a similar role to that of ascorbate, i.e. intermediate hydrogen carrier from substrates to oxygen.

The oxidase function of peroxidase was later shown towards other compounds, such as: glutathione, hydro- and naphtoquinone, fluoroglycine and others. A necessary condition for the oxydase reaction was proved to be the presence of cofactors - manganese ions and various phenolic compounds. Further information on certain enzymatic reactions of dihydroxyfumaric and diketosuccinic acids in plant tissues was obtained by Stafford, Magaldi, and Vennesland [10] in 1954.

The role of dihydroxyfumaric acid in animal metabolism was evidenced for the first time in 1934 when it was found that the content of glycogen was increased in muscle on incubation with DHF [11]. Latter, was discovered a sequence of enzyme reactions as a pathway for glyconeogenesis, based on the observation suggesting the formation of a pentose (or a pentose phosphate) on addition of DHF and glyceraldehydes (or fructose-1,6-diphosphate and aldolase as a source of glyceraldehyde-3-phosphate) in rabbit muscle extract. The sequence of reactions leading from DHF to 3 -ketopentose 5 is given as follows [12].

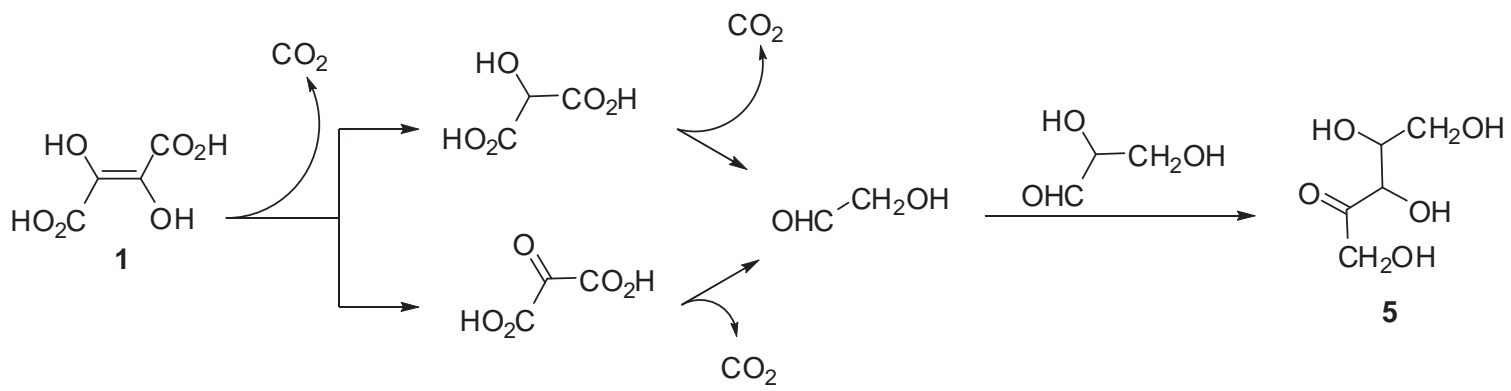

Scheme 4

It is well known that di - and tricarboxylic organic acids play an important role in plant and animal metabolism. Products of carbohydrates transformations, they participate in the biosynthesis of alkaloids, glycosides, amino acids and other biologically active compounds. The dihydroxyfumaric acid is linked to the cycle of di- and tricarboxylic acids, and with the glyoxalic cycle via tartaric acid transformation cycle, as depicted below, in Figure 1.

Without going into details, it should be mentioned that the main function of these cycles consists in that they represent the final collective path of oxidation of carbohydrates, lipids and proteins, as during metabolism processes, glucose, fatty acids and amino acids are transformed either into acetyl-CoA, or in intermediate compounds of cycles mentioned above.

The dihydroxyfumaric acid is formed from tartaric acid by dehydrogenation, in the presence of nicotinamide adenine dinucliotide (NAD) and tartaric acid dehydrogenase, and bivalent iron.

The dihydroxyfumaric acid is involved in metabolism during grapes ripening. Although it is found in small amounts in grapes, it serves as a catalyst for redox reactions. Dihydroxyfumaric acid is easily oxidized by DHF oxidase. Therefore, grapes contain the products of its disintegration: mesoxalic acid, glycolic acid and oxalic acid and glyoxalic acid.

Dihydroxyfumaric acid is of importance in winemaking industry and in food industry. It is well known that organic acids contribute to the formation of acidity of wines - one of the major important wine characteristics. Although its content in wine is small, DHF plays an important role in reduction processes occurring in wine. 


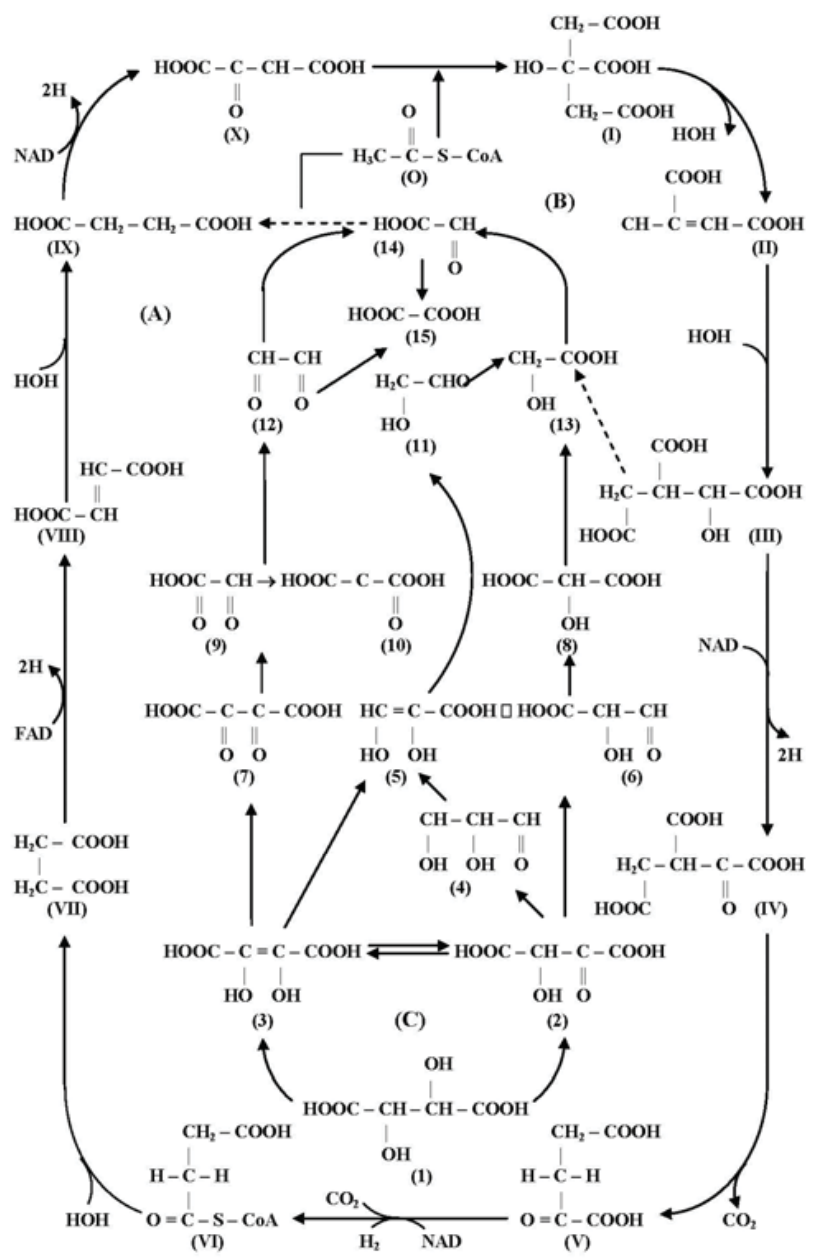

Figure 1 (from [9]). Interrelation of metabolic cycles (picture from Duca Gh., PhD thesis, 1979).

(A) - cycle of tricarbonic acids (Krebs cycle), (B) - glyoxalate cycle, (C) - cycle of dicarbonic acids (Baroud cycle). I - citric acid, II-cis-acinitic acid, III-iso-citric acid, IV-oxalo-succinic acid, V-a-ketoglutalic acid, VI-succinoxoenzyme A, VII - succinic acid, VIII - fumaric acid, IX-maleic acid, X-oxalo-acetic acid. 0 - acetyl coenzyme A; 1 - tartaric acid, 2 - oxaloglycolic acid, 3 - dihydroxyfumaric acid; 4 - reductone of triose, 5 - dixydroxyacrilic acid, 6 - semialdehyde of tartronic acid; 7 - diketosuccinic acid, 8 - tartronic, 9 - glyoxylcarbonic, 10 - mezoxalic acids; 11 - glycolic aldehyde, 12 - oxalic aldehyde; 13 - glycolic acid, 14 - glyoxalic acid, 15 - oxalic acid.

If the access of air to wine materials during processing and maturation is limited and within a year the wine absorbs no more than 3-5 mg /L of oxygen, then, according to Rodopulo [13], under these conditions, tartaric acid is oxidized to dihydroxyfumaric acid determining a low redox potential of the wine, and the reductons restore oxidized substances, which contributes to the development of taste and flavor characteristic to table wines. However, DHF decomposes easily in aerobic conditions, and that is the reason for which it is hard to determine it in wines.

To improve the stability of wines in time and to improve their hygienic properties, a series of experiments were performed by Sychev and Duca [14], using dihydroxyfumarate for wine materials preservation. It was shown that due to its pronounced reduction properties DHF transforms oxidized components of grape drinks in their reduced forms. When added to the sample, DHF was consumed by interaction with oxidized polyphenols, while the latter were reduced. That fact reduces the possibility of formation of colloidal haze in wine, and dihydroxyfumarate can be used in certain amounts as a preservative. In this case, oxidation of DHF occurs into diketosuccinic acid, with its further decarboxylation.

It was noticed that compared to the wine obtained according to the conventional technology, the wine made with the addition of dihydroxyfumarate exhibited better taste and a considerably greater stability.

Antioxidant properties of dihydroxyfumaric acid were also appreciated in studies regarding the inhibition of nitrosation of secondary aliphatic amines and amides. It was shown [15] that under the action of DHF, nitrosating agents are inactivated, therefore the formation of harmful nitrosoamines is supressed. 
The inhibitory activity of dihydroxyfumaric acid and its sodium salt was investigated in the process of nitrosatoin of metabolites formed in gastric juice. It was found that during albumin and casein proteolysis by proteolytic enzymes, these reagents inhibit the formation of N-nitrozocompounds without having any influence on the content of unhydrolyzed protein substrate or the concentration of formed amino acids [15].

Also, it was found [16] that the sodium salt of DHF decreases the speed of methaemoglobin formation during oxidation of hemoglobin with nitrites, by decreasing the acceleration factor with increasing reducton concentration. Research in the endogenous formation of N'-nitrosonornicotine (one of the most abundant strong carcinogens in unburned tobacco and cigarette smoke) in rats demonstrated efficient inhibition (86\%) of this process by dihydroxyfumaric acid [17]. Studies regarding the formation of N'-nitrosoamines in meat products (smoked, fried, dried, salted products) demonstrated that the sodium salt of dihydroxyfumaric acid significantly decreased the concentration of nitrites and nitrates in meat products [15].

\section{Chemistry of dihydroxyfumaric acid}

It is well known that the spatial structure of a compound significantly affects its properties, including its biological activity. One of the ways used to solve such problems is the implementation of the synthesis of the desired derivative from natural renewable starting materials. In the directed synthesis of substituted 1,2-dihydroxyethylenes a suitable starting compound is dihydroxyfumarate 1 [18-20]. This, along with the peculiar structure makes it an attractive and indispensable source for the implementation of the synthesis of substances with desired properties.

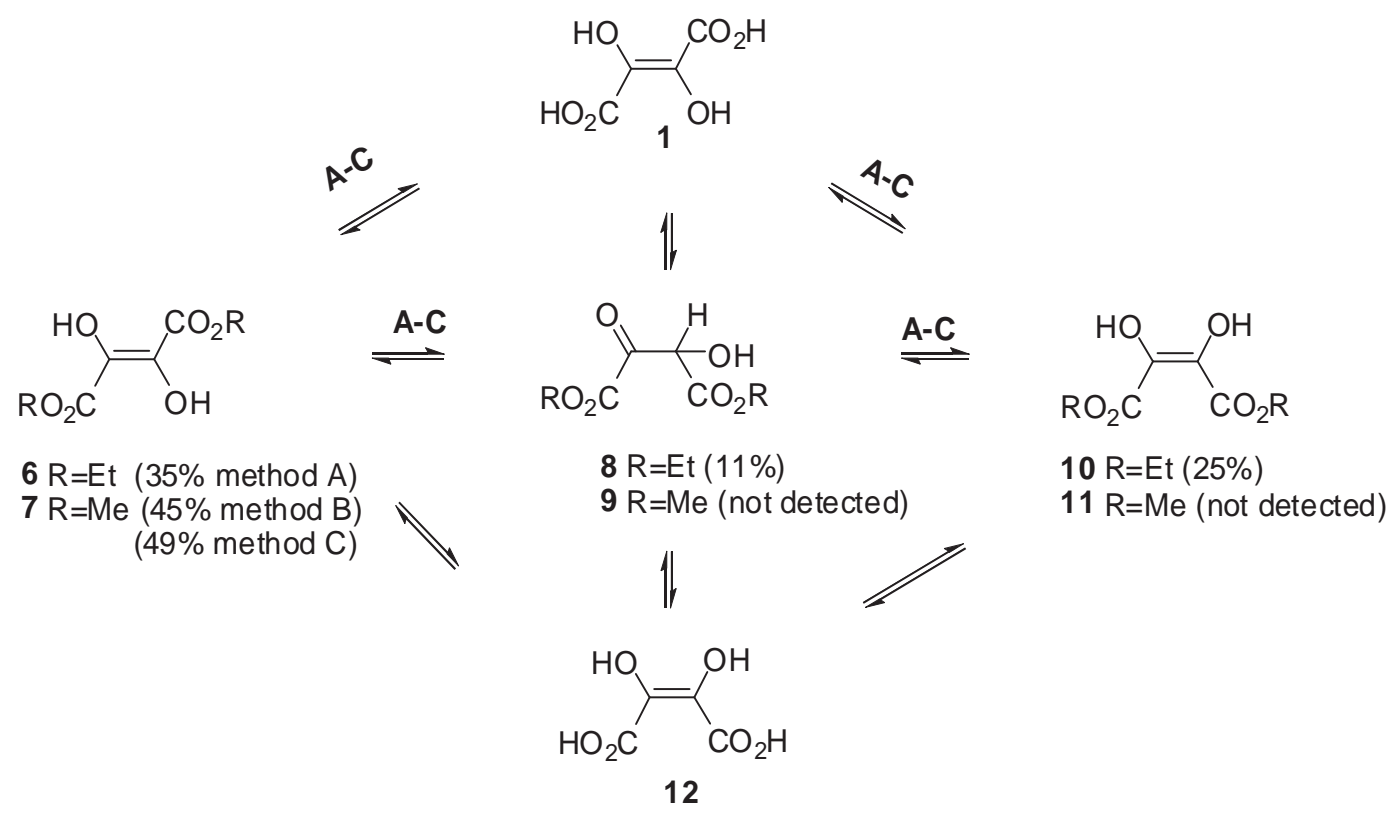

A: $\mathrm{EtOH} / \mathrm{HCl} ; \mathrm{B}: \mathrm{MeOH} / \mathrm{HCl} ; \mathrm{C}^{\mathrm{CH}_{2} \mathrm{~N}_{2} / \text { ether }}$

Scheme 5

Given the structure of acid 1, the attack of reagents on its molecule is directed generally to the carboxyl or hydroxyl group. Further transformation of the resulting adducts leads to compounds with greater or smaller number of carbon atoms than the starting material. On the other hand, the tendency to keto-enol tautomerism of substance 1, and as a consequence of the isomerization of trans-isomer 1 in the cis-isomer 12 made Hartree E. F. explore the configuration of its esters [18].

The mixture of ethylic esters $6,8,10$ was synthesized by prolonged maintenance of acid 1 in ethanol/HCl. An analogical approach was used for the homologues 7,9 and 11. However, only the methylic ester 7 was isolated. Alternatively, the substance 7 was synthesized by methylation with diazomethane.

The comparison of acid 1 with compounds of related structure in terms of dissociation constants and chemotactic properties gives evidence for trans structure in aqueous solution. The formation of a grey-brown color with $\mathrm{FeCl}_{3}$ (violet on addition of alkali) is in contrast to the customary green color expected with cis $\mathrm{OH}$ groups. Since both esters retain the ene-diol group they must be considered as trans and cis, respectively. The fact that ethylation and methylation carried out under very similar conditions with alcohols/ $\mathrm{HCl}$ yields products of different structures is perhaps due to the different solubility of related ethyl and methyl esters in respective reaction mixtures. Thus after $\mathrm{ETOH} / \mathrm{HCl}$ treatment, compounds 
3 and 5 can be isolated while after $\mathrm{MeOH} / \mathrm{HCl}$ treatment, only the ester 7 (identical with that prepared with $\mathrm{CH}_{2} \mathrm{~N}_{2}$ ) can be detected. Since a partial conversion of compound 6 into 10 can be shown to occur under acidic conditions of esterification, and since methyl ester is not accompanied by other isomers after methylation under analogous conditions, it is reasonable to conclude that the trans structure is the initial product 1 .

Interest in the mechanism of oxidation and isomerization of cis-and trans-enediols prompted Goodwin et al [19] to attempt the preparation of derivatives 13-18 starting from acid 1 (see Scheme 6).

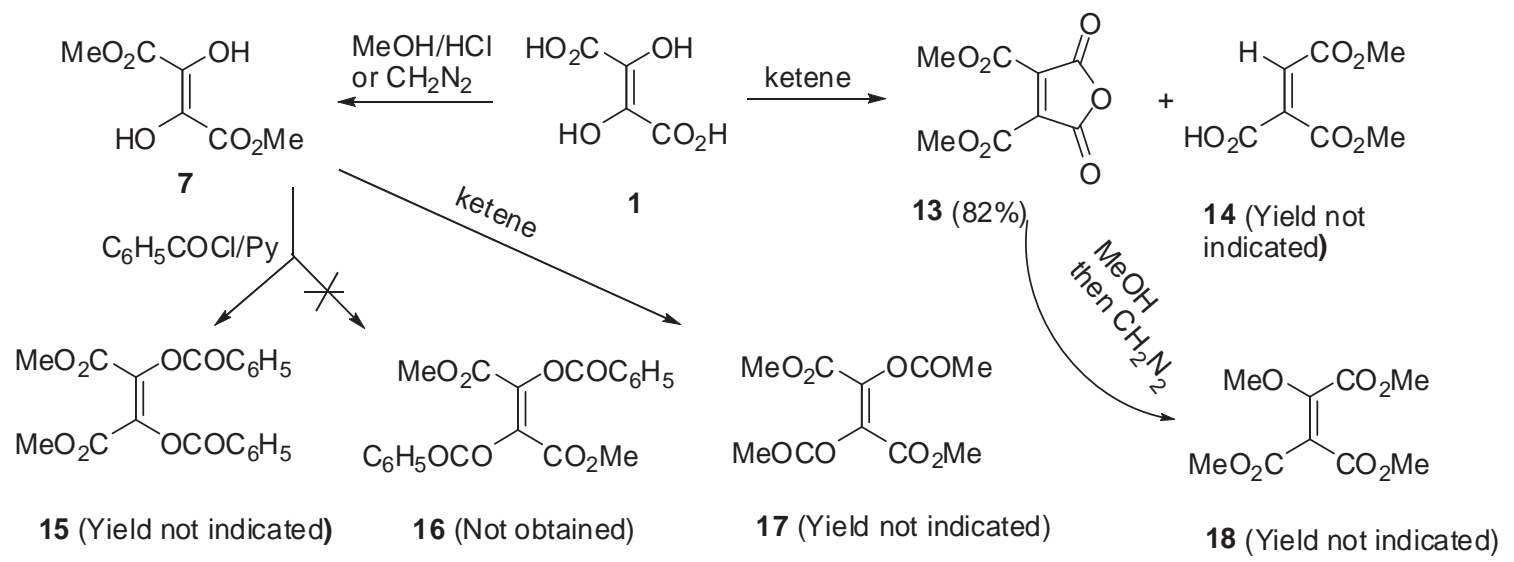

Scheme 6

Benzoylation of trans-enediol 7 by action of $\mathrm{BzCl} / \mathrm{Py}$ leads to centro-symmetrical dimethyl dibenzoylfumarate 15. The formation of trans-dimethyl dibenzoylfumarate 16 was not detected. The trans- ester 7 with ketene yielded the trans-diacetyl ester 17. As a by-product in the preparation of $\alpha, \beta$-unsaturated five-membered lactone 13, the compound 14 was isolated. Notable, only if in the acetylation of trans-enediol 1, decarboxylation occurred prior to anhydrization the product 14 may have the trans-configuration.

The action of various silylating agents on acid 1 has been investigated [20-22].

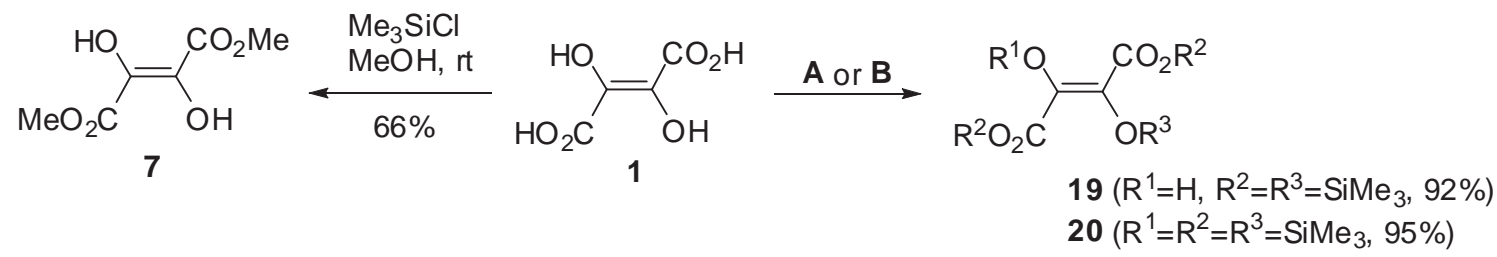

A: $\mathrm{Me}_{3} \mathrm{Si}-\mathrm{acac}, 70^{\circ} \mathrm{C} ; \mathrm{B}: \mathrm{C}_{3} \mathrm{H}_{5} \mathrm{SiMe}_{3}, \mathrm{CF}_{3} \mathrm{SO}_{3} \mathrm{SiMe}_{3}, \mathrm{MeCN}, \mathrm{rt}$

\section{Scheme 7}

2,4-Pentanedione trimethylsilyl enol ethers ( $\mathrm{Me}_{3} \mathrm{Si}$-acac) converted enediol 1 into the mono-acid 19.

The product 20 was obtained after the silylation of dihydrofumaric acid 1 with allyltrimethylsilane and trimethylsilyl triflate in acetonitrile at room temperature.

The new esterification of acid 1 with $\mathrm{MeOH}$ under the action of trimethylsilyl chloride was performed. An anhydrization with formation of homologue five-membered lactone 13 (see Scheme 7) was not observed in any reactions with participation of silylations agents.

Nitrogen containing derivatives of dihydroxyfumaric acid 1 may open new possibilities in organic synthesis: selecting of appropriate combinations of substituents may allow adjusting the polarity in wide ranges, the solvating ability, catalytic properties and thereby influence the depth and selectivity of the reaction.

The conversion of esters to amides is a useful reaction, and different amides can be prepared this way from appropriate amines. The reaction is particularly useful because the ester is easy to prepare, even in cases where the corresponding acyl halide or anhydride is not. Although more studies have been devoted to the mechanism of acylation of amines with esters than with other reagents, the mechanistic details are not yet entirely clear. Under the normal alkaline conditions, the reaction is base-catalyzed, indicating that a proton is being transferred in the rate-determining step and that two molecules of amine are involved.

In an effort to determine the role of hydrogen bonding in stabilizing secondary structure and to develop means of 
predictably enhancing the tendency of functionalized peptides 23 to assume sheet or helical conformations starting from ester 3 has been prepared 2,8-diaminoepindolidione 22 [23].

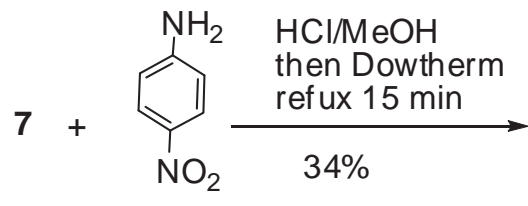<smiles>COC(=O)c1[nH]c2ccc([N+](=O)[O-])cc2c(=O)c1Nc1ccc([N+](=O)[O-])cc1</smiles>

$\mathrm{SnCl}_{2}$ then
$\mathrm{NaAlCl}_{4}, 160^{\circ} \mathrm{C}, 1 \mathrm{~h}$
$60 \%$<smiles>Nc1ccc2[nH]c3c(=O)c4cc(N)ccc4[nH]c3c(=O)c2c1</smiles><smiles>[R4]C(NC(=O)C([R4])NC(=O)C([R4])NC(=O)C([R2])N(C)C)C(=O)NC([R])C(=O)NC([R])C(=O)N(C)C([R])C(=O)NC([R])C(=O)N(C)C</smiles>

\section{Scheme 8}

The amino-de-methylation of the ester 7 by $p$-nitroaniline followed un-catalyzed high-temperature cyclization to form the quinolone 21 in an overall yield of 56\%. Diamine 22 derived form carbomethoxyquinolone 21 further was transformed into functionalized peptides 23. The $\beta$-turn-forming tendencies of the 2,8-bis-(X-L-Pro-D-Ala) epindolidione, where $\mathrm{X}=\mathrm{Ac}$, Boc and COGlyOEt are assigned from ${ }^{1} \mathrm{H}$ NMR evidence.

Our group has been engaged in the synthesis and properties recognition of other amides (Scheme 9) [21].
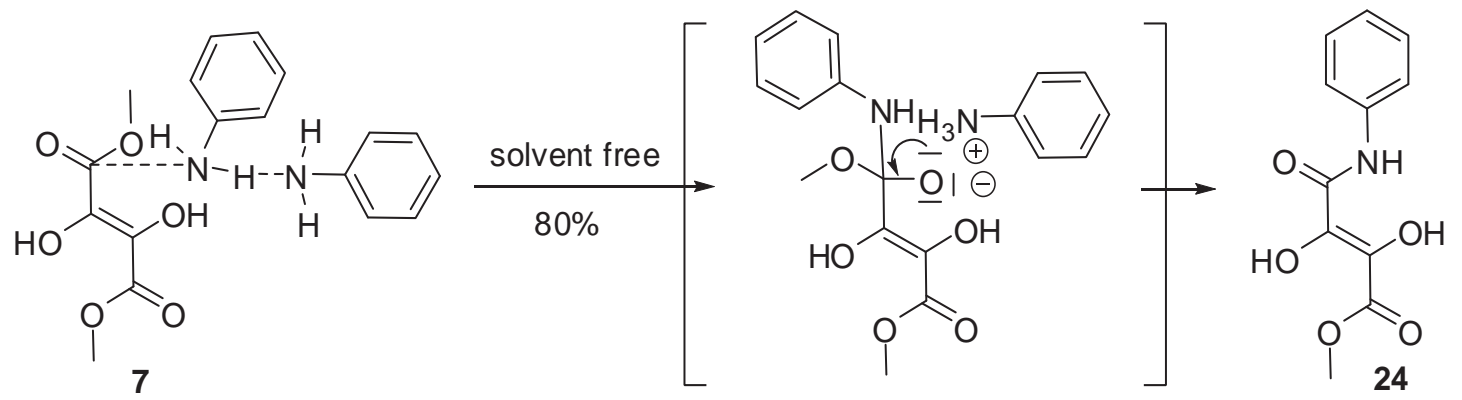

Scheme 9

Heating of the ester $\mathbf{3}$ in aniline during two hours leads to the formation of monoamide $\mathbf{2 4}$.

Increasing the reaction time and temperature to the boiling point of aniline didn't lead to the formation of bis-anilide. It should be mentioned that the tentative of synthesis of the mixed amide by heating ester 20 with monoethanolamine wasn't successful, either.

An interesting result in the reaction of amidation of ester 7 was obtained when replacing aniline with its nitrogencontaining analogue - 2-aminopyridine (Scheme 10). 


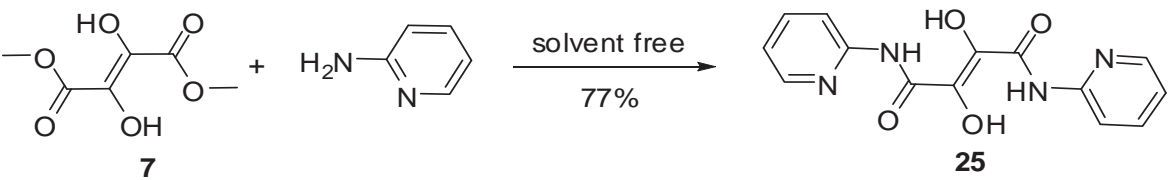

\section{Scheme 10}

Therefore, replacing the carbon atom in the benzene ring with nitrogen in the initial amine, had a significant influence on the character of the formed compound 25.

The influence of the nature of homologues of monoethanolamine on the reaction rate and physico-chemical properties of dihydroxymaleinic acid amides was investigated.

If the amidation is carried out at room temperature by using ester 7 and monoethanolamine, the reaction product is bis-amidoalcohol 26.

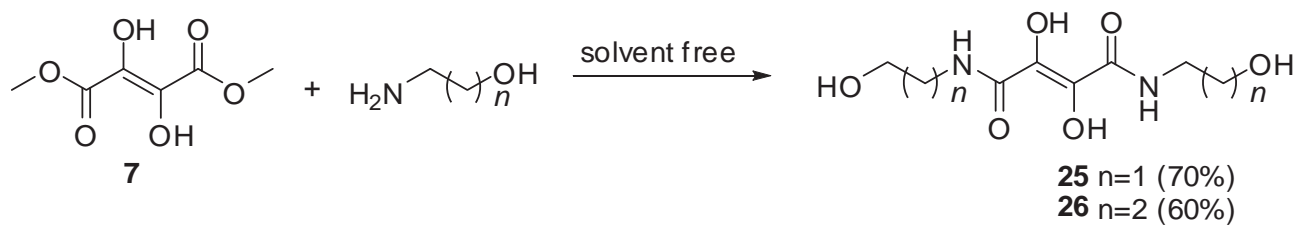

\section{Scheme 11}

Increasing the alkyl radical by one methylene fragment in the initial aminoalcohol gave the decrease of the total yield of product 27 .

The presence of two methyl groups in the $\alpha$-position to the amino group in the initial 2-amino-2-methylpropan1-ol didn't decrease the yield of the target diamide 27. Analogically to the previous synthesis, this reaction was performed at room temperature.<smiles>COC(=O)/C(O)=C(\O)C(=O)OC</smiles><smiles>[R]CC(N)(C[R])C[R]</smiles>

solvent free

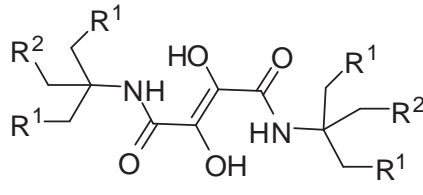

$27 \mathrm{R}^{1}=\mathrm{H}, \mathrm{R}^{2}=\mathrm{OH} \quad(75 \%)$

$28 \mathrm{R}^{1}=\mathrm{OH}, \mathrm{R}^{2}=\mathrm{OH}(69 \%)$

$29 \mathrm{R}^{1}=\mathrm{R}^{2}=\mathrm{H}$

\section{Scheme 12}

The transformation into the 2-amino-2-(hydroxymethyl)propane-1,3-diol decreased the reactivity of the amine. According to TLC data, only in the case of heating of initial reagents at $50^{\circ} \mathrm{C}$ the formation of the product was observed. Following processing of the reaction mass with a yield of $69 \%$, was separated $\mathrm{N}^{1}, \mathrm{~N}^{4}$-bis(1,3-dihydroxy-2(hydroxymethyl)propan-2-yl)-2,3-dihydroxyfumaramide 28.

It should be mentioned that the homologue 29 may be synthesized at room temperature by mixing of tert-butyl amine with diether 7 . In this case, the yield of the target product is practically the same with the mentioned above.

The benzimidazole nucleus has been of considerable interest since it was noted that benzimidazole inhibits the growth of certain yeasts and bacteria. Such heterocyclic systems can be modified not only by changing the nature and the number of the connecting atoms but by changing the nature of the substituents in the benzimidazole nuclei as well. Scientific literature revealed the fact that a number of bis-benzimidazoles have been reported but apparently none of them have been synthesized from dihydroxyfumaric acid $\mathbf{1}$.

On the other hand the methods were developed to synthesize novel mono and bis-benzimidazoles where the both benzimidazole nuclei are united through their 2-positions either through ethen-1,2-diols (see Scheme 13).

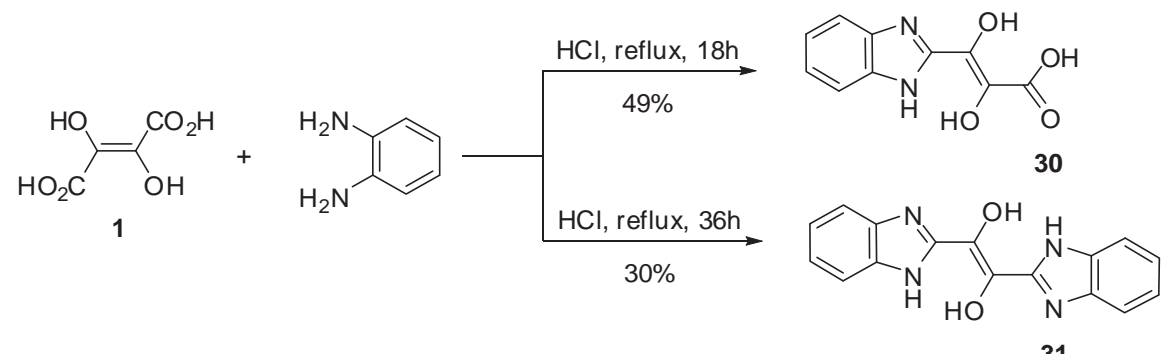

Scheme 13 
The benzimidazole 30 was synthesized by hydrochloric acid-catalyzed condensation of the o-phenylenediamine with a dihydroxyfumaric acid 1 an oil bath at $135^{\circ}$ under $\mathrm{N}_{2}$. The same procedure has been used to prepare bisbenzimidazoles $\mathbf{3 1}$ by refluxing two moles of diamine with one mole of a dihydroxyfumaric acid $\mathbf{1}$ in $4 N$ hydrochloric acid.

Cucurbiturils Q $[n]$ are substance which composed of 6 glycoluril rings and 12 methylene bridges [24]. It should be noted that cucurbiturils $\mathrm{Q}[n]$ has been demonstrated different application including the preparation of molecular and ion complexation [25-32], the catalysts [32-34], non-covalent modification of dendrimers [18], molecular necklaces [36,37], molecular switches [38,39], DNA complexes [40] and bowls [41].

Preparation of glycoluril monomers from dihydroxyfumaric acid 1 for expanded cucurbiturils $\mathrm{Q}[n]$ uril reported in [42]. In the beginning authors investigated the formation of carboxylic acids 30 (Scheme 14).

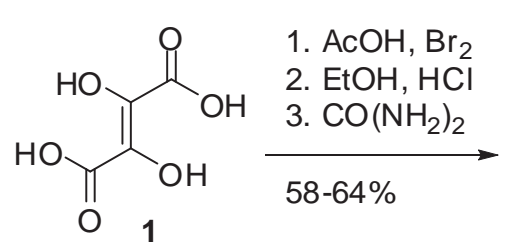<smiles>CCOC(=O)[C@@]12NC(=O)N[C@]1(C(=O)O)NC(=O)N2O</smiles>

Scheme 14

Conversion of esters 32 into acids 34 was possible by treatment of carboxylic salt 33 with an excess of p-toluenesulfonic acid (PTSA). On the other hand, the transformation of esters 32 into cyclic derivatives 36 as well as 37 has been realized according to Scheme 15.

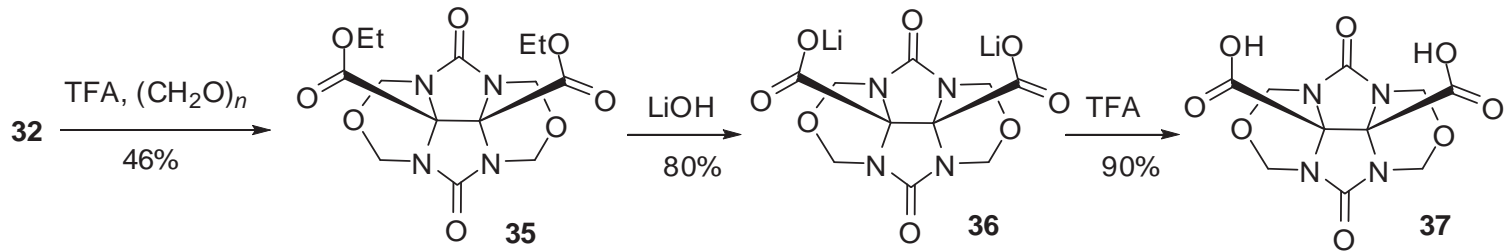

Scheme 15

Direct amidation reactions of esters 32 in neat primary amines at $75-90^{\circ} \mathrm{C}$ converts the esters into amide functional groups (see Scheme 16).

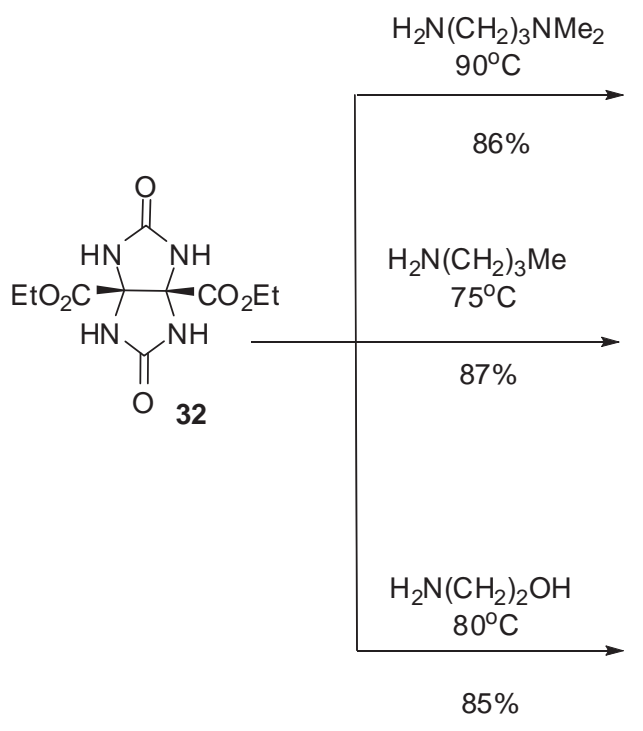

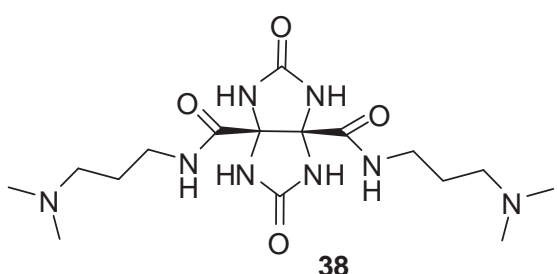

38<smiles>CCCCNC(=O)[C@]12NC(=O)N[C@@]1(C(=O)NCCCC)NC(=O)N2</smiles><smiles>O=C1N[C@]2(C(=O)NCCO)NC(=O)N[C@]2(C(=O)NCCO)N1</smiles>

Scheme 16 
Discovered that bulky esters 35 was highly reactive in direct amidation reactions with $\mathrm{N}^{1}$, $\mathrm{N}^{1}$-dimethylpropane1,3-diamine, butan-1-amine as well as 2-aminoethanol and provided amides in $88 \%, 90 \%$ and $93 \%$ yields, respectively (Scheme 17).
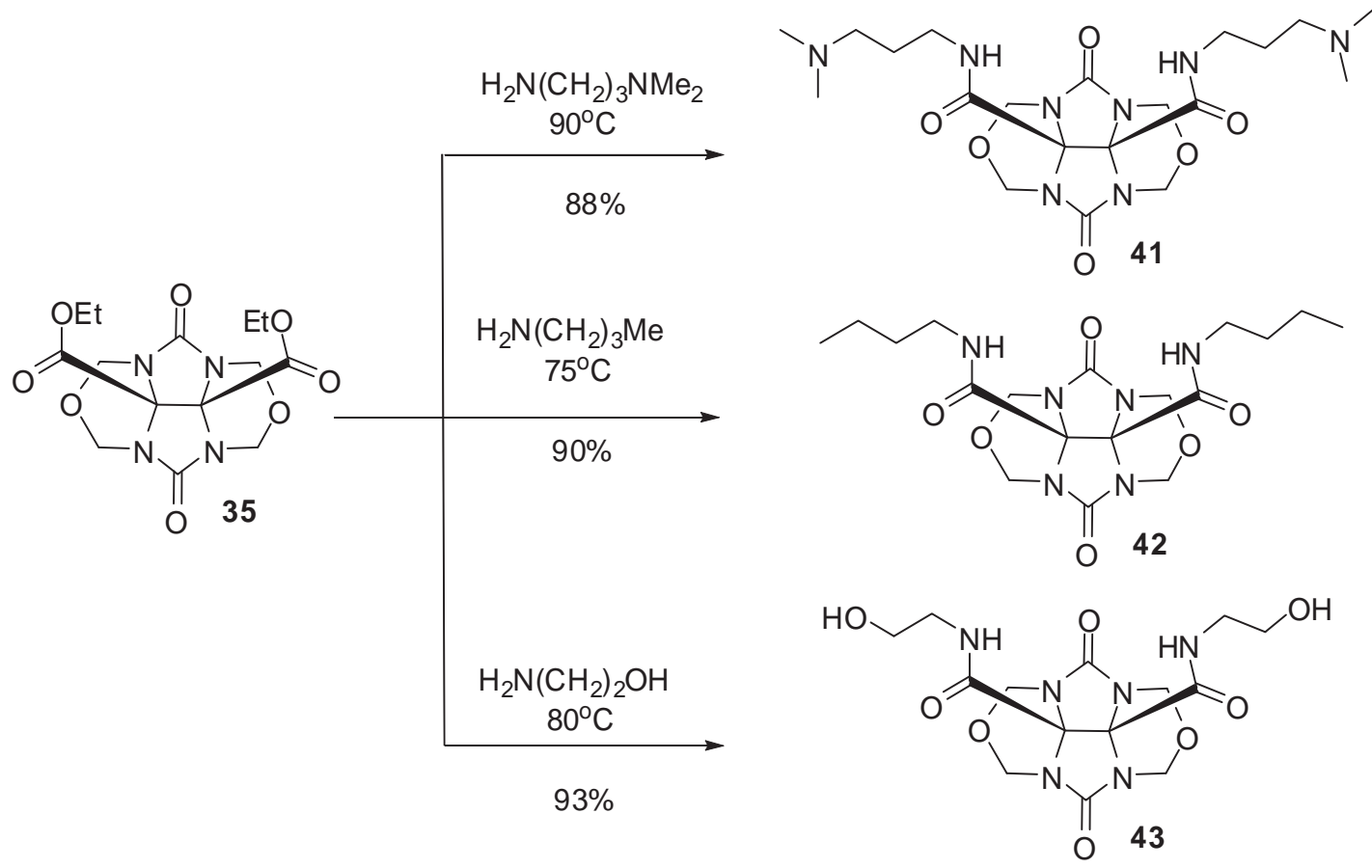

Scheme 17

The amidation of esters 32 and 35 by heating in neat morpholine at temperature up to $128^{\circ} \mathrm{C}$ afforded ammonium salts 44 and 45 rather than the desired tertiary amides (look Scheme 18).<smiles>CCOC(=O)N[C@]1(C(=O)OCC)NC(=O)N[C@@]1(C)C(=O)OCC</smiles>

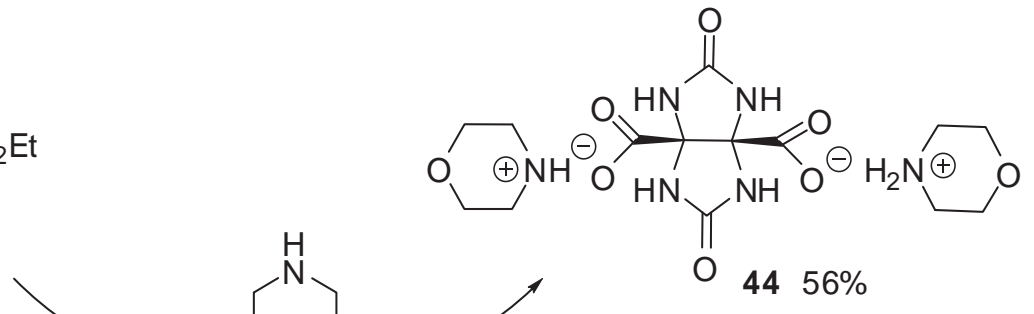<smiles>CCOC(=O)N1C(=O)OCN2C(=O)N3COCCN1C32C(=O)OCC</smiles>

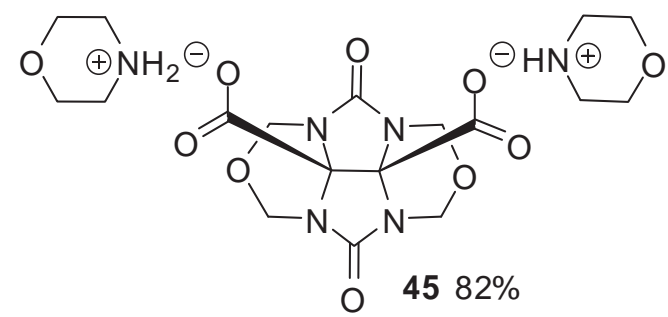

\section{Scheme 18}

On the other hand, conversion of diamides 38, 39 into the corresponding imides 46,47 by treatment with PTSA was realized via Scheme 19. 
<smiles>CN(C)CCCNC(=O)[C@@]12NC(=O)N[C@]1(C(=O)NCCCN(C)C)NC2=O</smiles><smiles>CCCCNC(=O)C12NC(=O)NC1(C(=O)NCCCC)NC(=O)N2</smiles><smiles>O=C1N[C@]2(C(=O)NCCO)NC(=O)N[C@@]2(C(=O)NCCO)N1</smiles>

40

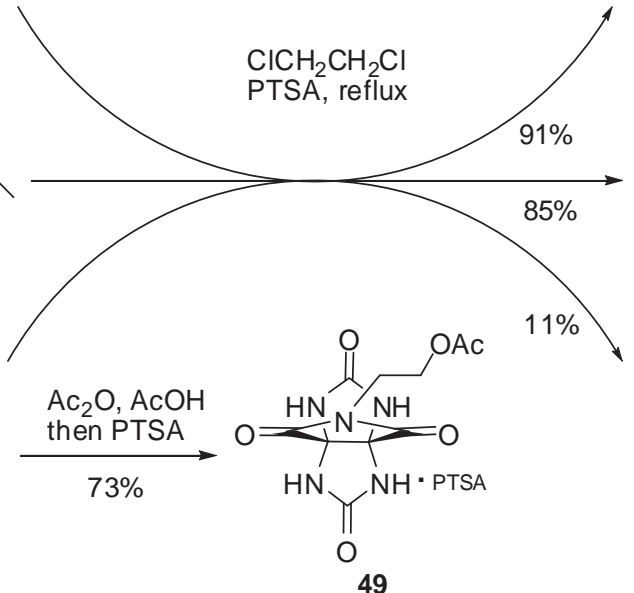

49
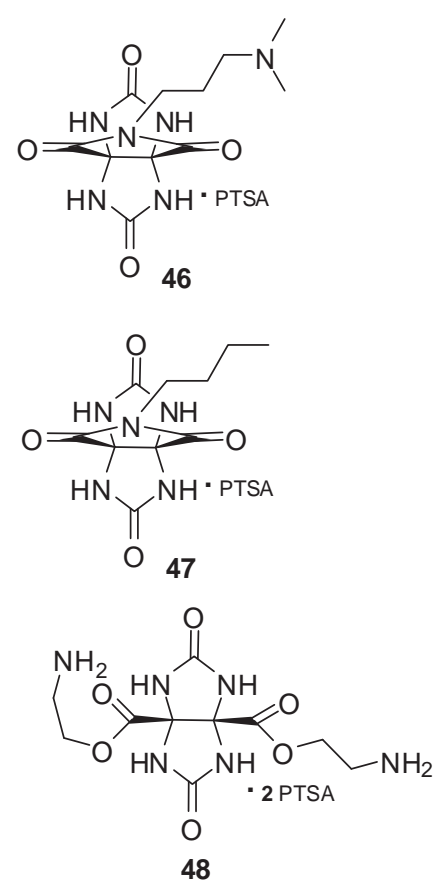

Scheme 19

Heating 40 under similar conditions did not result in the formation of the expected imide. In this case known [43] an $\mathrm{N}$ - to $\mathrm{O}$-acyl transfer reaction occurred instead delivering 48 as its PTSA salt. To prevent the $\mathrm{N}$ - to $\mathrm{O}$-acyl transfer reaction, acetylation followed ring closure in a single step afforded target compound 49 in $73 \%$ yield.

The transformation of compounds 41 and 42 into imides 50 and 51 occurred without incident in comparatively good yields (66\% and $82 \%$, respectively) (Scheme 20$)$.
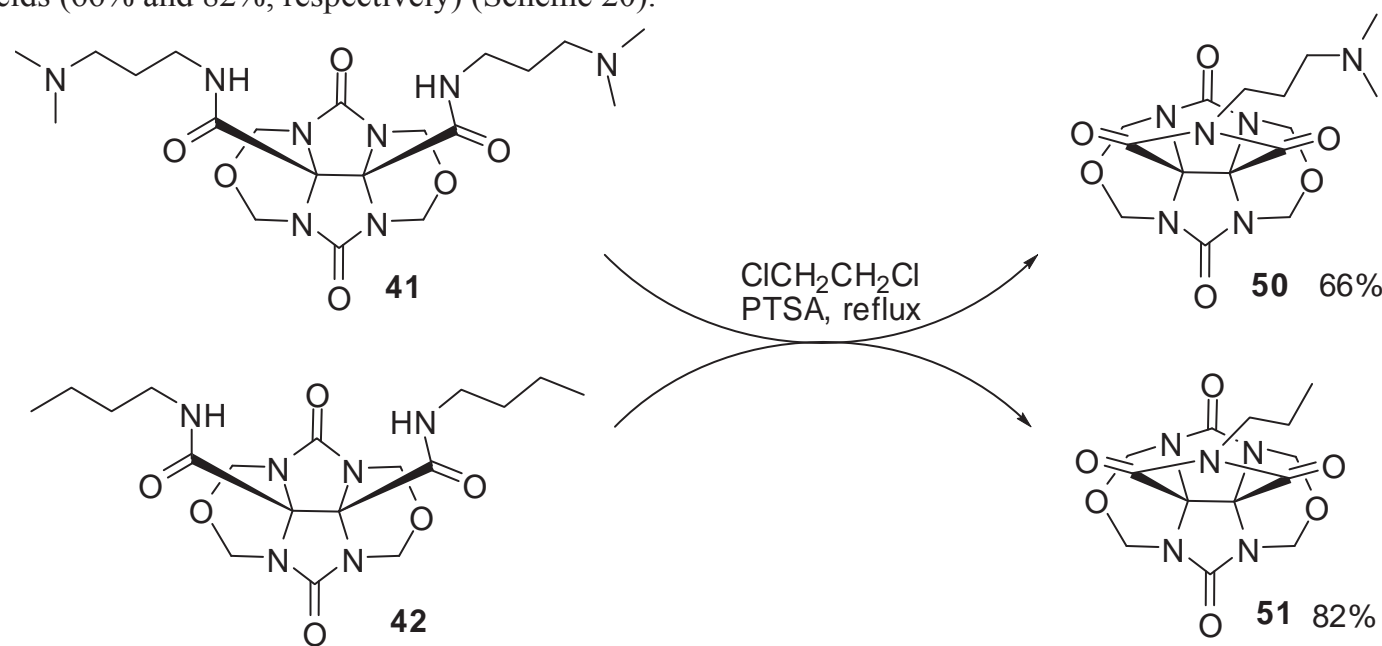

Scheme 20

Similarly with diol 40, compound 43 was converted into acetate 52 in $73 \%$ yields (scheme 21).

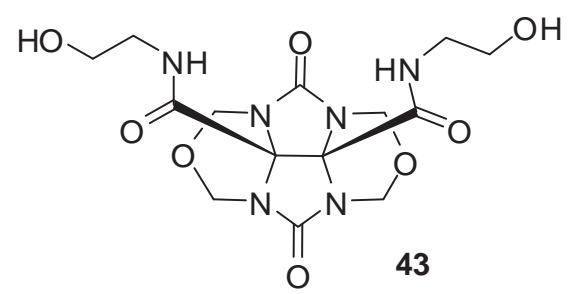

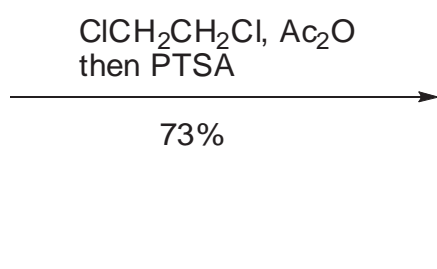

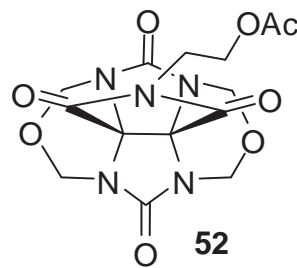

Scheme 21 
Synthesized building blocks bearing free ureidyl group and bis-cyclic ethers could be used for construction of cucurbituril, its derivatives, and its congegenes.

The introduction of two aromatic arms would provide $\pi$ - $\pi$-stacking surfaces that encourage strong interactions with substrate. However, aromatic amines have not been reported in such type of Mannich reaction, probably because aromatic amines have lower reactivity compared to aliphatic amines. Other group has developed a new generation of molecular clips from acid 1 with stronger binding capability and rigidity (Scheme 22) [44].
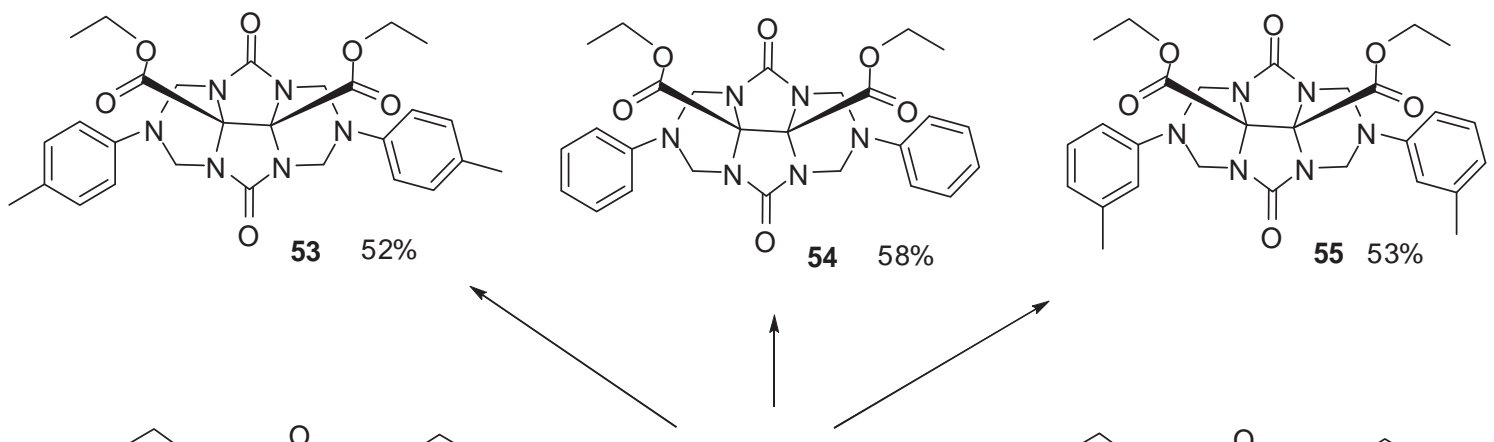

$5458 \%$

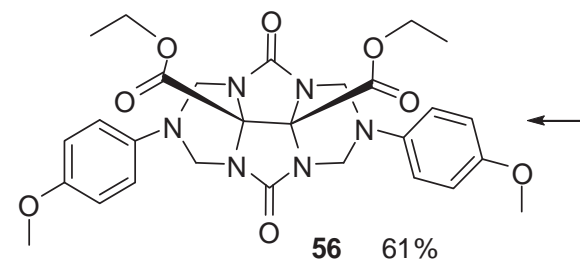<smiles>CCOC(=O)[C@]12NC(=O)N[C@]1(C(=O)OCC)NC(=O)N2</smiles>

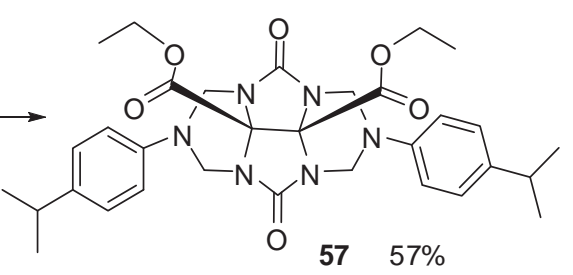

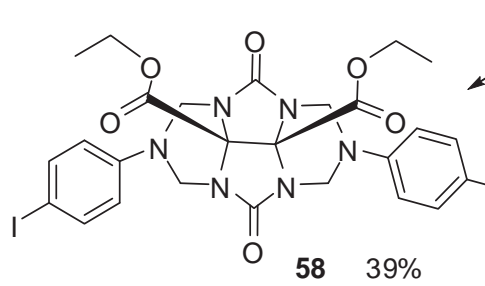

32

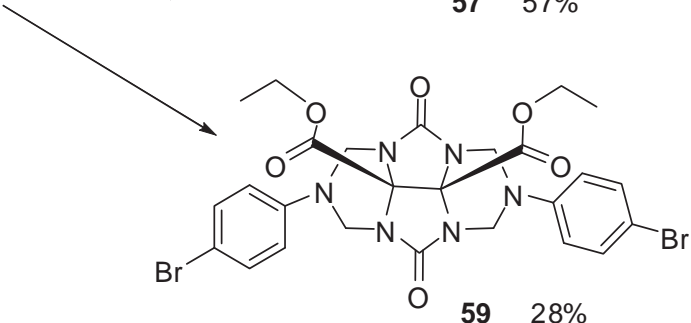

Scheme 22

The esters 32 reacted with aromatic amines in presence of $37 \%$ aqueous formaldehyde with formation expected substances 53-59.

Electron-rich amines like para-nitroaniline and para-aminopyridine have not reacted, even when the temperature was elevated and the reaction time was prolonged. DMF was the optimal reaction solvent, because diethoxycarbonyl glycoluril 32 and the products have good solubility characteristics.

Synthesized clips 53-59 can bind 1,3-dihydroxy-substituted aromatic quests by means of hydrogen bonding between the hydroxyl groups of the guest and the urea carbonyl group of the host and by $\pi$ - $\pi$-stacking interactions between the guest and the host sidewall. However such investigation has been realized.

One area of glycoluril derivatives that has been less well explored is their utilization as fluorescent chemosensors for anions [45].

A novel class of fluorescent diethoxycarbobyl glycoluril derivatives with aryl alkyne side chains 61-68 starting from dihydroxyfumaric acid 1 was synthesized via alkylation and subsequent Sonogashira cross-coupling reactions according Scheme 23 [46].

Urea 32 was alkylated with 1,2-bis(bromomethyl)-4,5-dibromobenzene using $t$-BuOK as base in anhydrous DMSO in $59 \%$. The variety of substrates were used in coupling reaction which accomplished using $\mathrm{Pd}\left(\mathrm{PPh}_{3} \mathrm{Cl}_{2}\right) / \mathrm{CuI}_{\mathrm{I}}$ catalysts in presence of $\mathrm{Et}_{3} \mathrm{~N}$ in $\mathrm{DMF}$ at $100^{\circ} \mathrm{C}$. The yields were not affected drastically in the presence of either electrondonating or electron-withdrawing group on arylacetylene. The photophysical properties of synthesized compounds were examined in MeCN. Substances 61, 64 and 65 exhibited a similar $\lambda_{\max }$ of emission (368-370 nm). Fluorescence maximum wavelengths of other derivatives differed from each other. Compared to 61 with an emission maximum at 370 $\mathrm{nm}$, the imission spectrum of 68 exhibited a $32 \mathrm{~nm}$ bathochromic shift due to the larger $\pi$-conjugation of the naphthyl group as compared to that of the phenyl group of 61 . Similarly, red shifts of compounds 62,63 and 67 with respect to 61 were presumably attributed to more electron-donating nature of the substituent groups. 


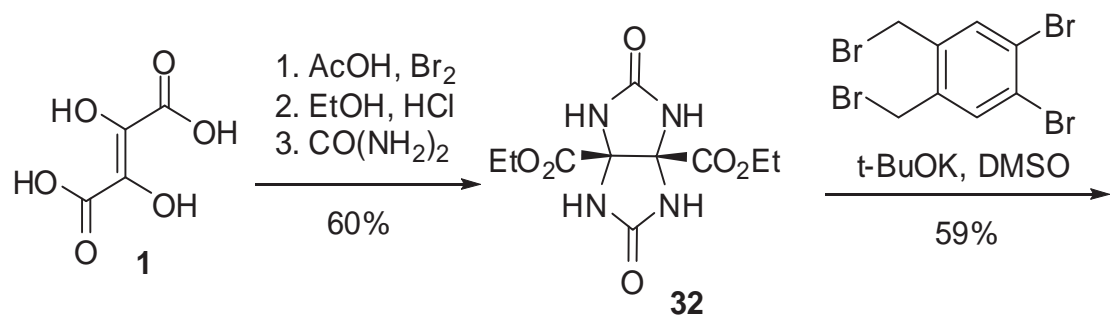<smiles>CCOCC1(OCC)NC(=O)N2Cc3cc(Br)c(Br)cc3CN1C(=O)N2</smiles>

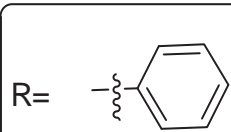

61<smiles>CC(C)(C)c1ccc(O)cc1</smiles>

62<smiles>Cc1ccc(C(N)=O)cc1</smiles>

66
$\mathrm{R}-\mathrm{C} \equiv \mathrm{CH}$ $\mathrm{Pd}\left(\mathrm{PPh}_{3}\right)_{2} \mathrm{Cl}_{2}$ $\mathrm{Et}_{3} \mathrm{~N}, \mathrm{DMF}$<smiles>[R]C#Cc1cc2c(cc1C#C[R])C(=O)N(C)C1(OCC)N(C2)C(=O)NC1(C)OCC</smiles>

61 (yield 75\%)

62 (yield 78\%)

63 (yield 80\%)

64 (yield 69\%)

65 (yield 65\%)

66 (yield 73\%)

67 (yield 70\%)

68 (yield 70\%)

4-Nitrophenol has mutagenic properties and its use in active ester coupling reactions and previously was complexed by cyclodextrin, calixarene, and cucurbit[n]uril molecular containers [47-52]. The synthesis and highly selective recognition properties of fluorescent molecular clip 70 toward 4-nitrophenol reported [53].<smiles>O=C(O)C(O)=C(O)C(=O)O</smiles>

1. $\mathrm{AcOH}, \mathrm{Br}_{2}$ 2. $\mathrm{EtOH}, \mathrm{HCl}$ 1<smiles>CCOC(=O)C(=O)C(=O)OCC</smiles>

urea, TFA benzene reflux<smiles>Nc1cccc2ccccc12</smiles>

\section{Scheme 23}


Alkylation of compound 32 with two equivalent of 2,3-bis(bromomethyl)-1,4-dibromobenzene under basic conditions (see Scheme 19) gave product 69 in 39\% yield. Installation of the 4-methoxyphenylethynyl arms by use known method [54] afforded molecular clip 70 in $72 \%$ yield.

It should be noted that significant fluorescence quenching which was observed only for 4-nitrophenol but not for any of other phenols.

Many fluorescent molecular sensors and switches are known for heavy and transition metal ions such as $\mathrm{Zn}^{2+}$, $\mathrm{Hg}^{2+}, \mathrm{Pb}^{2+}$, and $\mathrm{Cu}^{2+}$ have been developed [55-68]. But, there is examples of specific fluoresensors for Fe $\mathrm{Fe}^{3+}$ still scarce [67-72].

Iron is an essential element for humans and plays an important role in biochemical and nutritional processes. Many proteins and enzymes contain ferric ions either for structural purposes or as part of a catalytic site [73].

A pair of novel molecular clips was synthesized from diethoxycarbonyl cyclic urea 35 and 1,2-dihydro-indazol3-one together with an evaluation of its utility as a new class of as fluorescent $\mathrm{Fe}^{3+}$ sensor reported in [74]. Target molecules 71,72 were synthesized as outlined in Scheme 25.

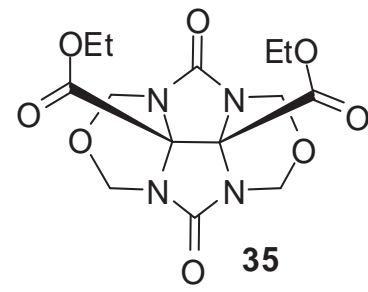
1,2-dihydroindazol-3-one, $\mathrm{MeSO}_{3} \mathrm{H}, 80^{\circ} \mathrm{C}, 3 \mathrm{~h}$

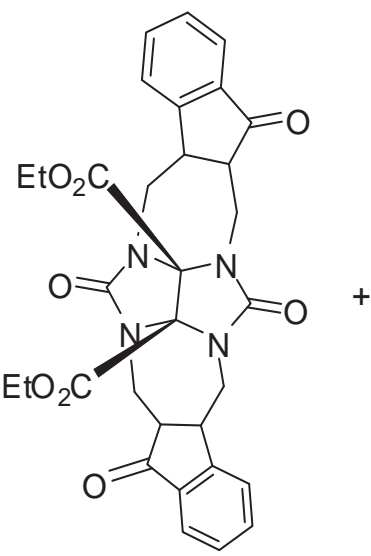

71

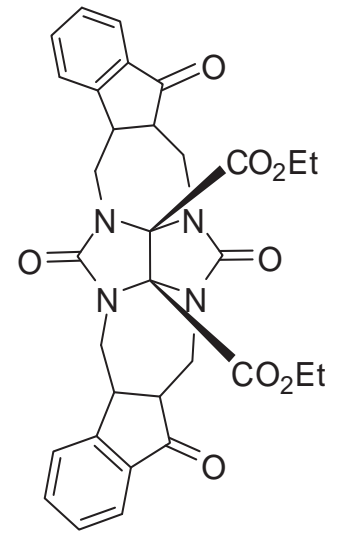

72

Scheme 25

The condensation of cyclic compound 35 with 2 equivalents of 1,2-dihydro-indazol-3-one in $\mathrm{MeSO}_{3} \mathrm{H}_{\text {at }} 80^{\circ} \mathrm{C}$ according to the method [75] afforded the pair of diastereomers 71 and 72 in $35 \%$ and $26 \%$ yields, respectively.

The chemosensory behaviour of isomers 71 and 72 were investigated by fluorescence measurements. It was discovered that sensors 71 and 72 have a higher selectivity for recognition of $\mathrm{Fe}^{3+}$ then for $\mathrm{K}^{+}, \mathrm{Mg}^{2+}, \mathrm{Hg}^{2+}, \mathrm{Cd}^{2+}, \mathrm{Zn}^{2+}$, $\mathrm{Co}^{2+}, \mathrm{Ni}^{2+}, \mathrm{Cu}^{2+}, \mathrm{Pb}^{2+}, \mathrm{Ce}^{3+}$ and $\mathrm{Cr}^{3+}$. Moreover, since molecular clips 71 and 72 have the same functional groups but different structures and conformations, in the same conditions, the fluorescence emission response of substance 71 is higher than of isomer 72 .

It has been reported that dihydroxyfumaric acid 1, in the presence of certain divalent metal ions, undergoes a sequence of oxidation and benzilic acid rearrangement to produce the trisubstituted methoxide ion $-\mathrm{OC}\left(\mathrm{CO}_{2}-\right)_{3}$, a previously undocumented oxidation of carbon, which generates the cubane-like core of a highly symmetrical octametallic complex [76]. Figure 2 represents a central molecule acting as a triple H-bond donor to one neighbor and as a triple H-bond acceptor from another neighbor.

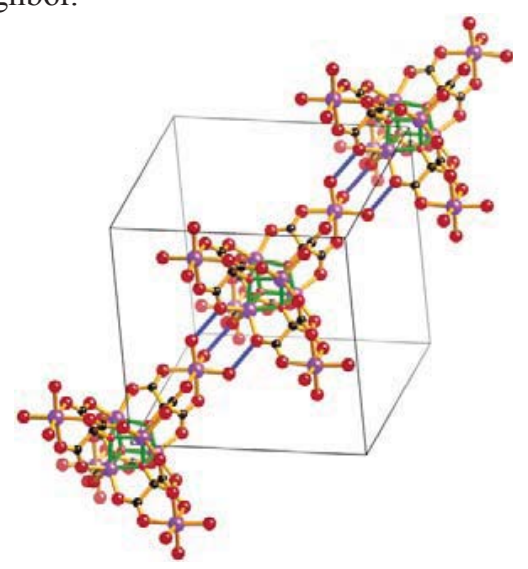

Figure 2. (Picture from [76]). 
It was reported that 2,3-dihydroxyfumaric acid in the presence of certain divalent metal ions in basic aqueous solution goes through an aerial oxidation and rearrangement [76,77].

A coordination polymer of composition $\left[\mathrm{Zn}_{6}\left(\mathrm{C}_{4} \mathrm{O}_{7}\right)\left(\mathrm{C}_{3} \mathrm{HO}_{5}\right)_{3}\left(\mathrm{H}_{2} \mathrm{O}\right)_{6}\right]\left(\mathrm{H}_{3} \mathrm{O}\right) 8 \mathrm{H}_{2} \mathrm{O}$ can be obtained in crystalline form (see Figure 3) from basic aqueous reaction mixtures at $40^{\circ} \mathrm{C}$ containing $\mathrm{Zn}$ (II) together with dihydroxyfumaric acid 1 [78].

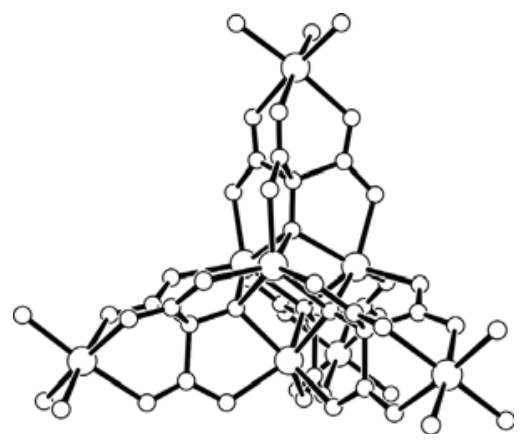

Figure 3 (from [78]).

This redox active compound 1 in basic aqueous solution can play a pivotal role in electron transfer processes, including acting as a reducing agent for a redox couple with high reduction potential and can exhibit rich electrochemistry.

On the other side, the stabilization of $\mathrm{CuI}$ complexes at open aerial atmosphere is a great challenge due to its intrinsic instability of the cuprous state and facile oxidation to $\mathrm{Cu}(\mathrm{II})[79,80]$.

It was reported the one step facile synthesis of $\mathrm{CuI}$ and $\mathrm{CuI} / \mathrm{CuII}$ mixed-valent coordination frameworks from different CuII-salts in aqueous solution at aerial atmosphere using DHF acid 1 as a reducing agent according Scheme $26[81]$.

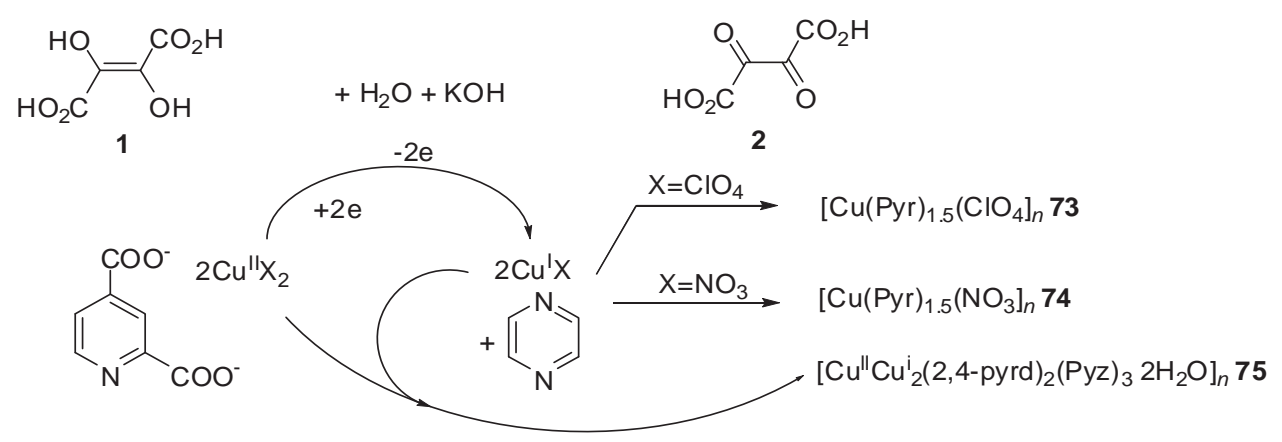

Scheme 26

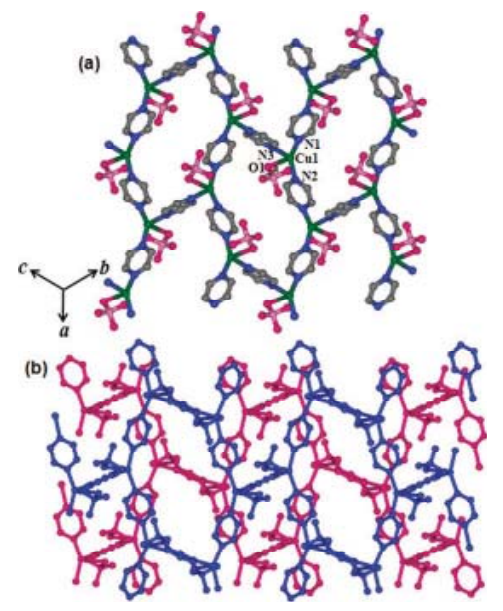

Figure 4

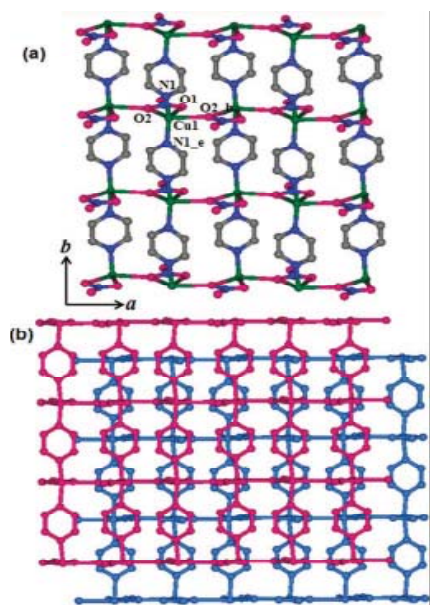

Figure 5

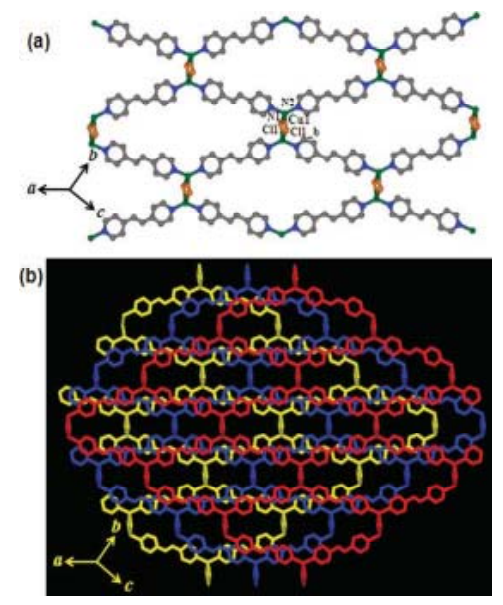

Figure 6

(Pictures from [81]). 
By changing the counter-anions, authors were able to produce three different CuI-frameworks with pyrazine and 1,2-bis(4-pyridyl)ethylene linkers $\left\{\mathrm{Cu}\left(\right.\right.$ pyrazine) $\left.1.5\left(\mathrm{ClO}_{4}\right)\right\} \mathrm{n} 73$ (Figure 3), $\left\{\mathrm{Cu}\right.$ (pyrazine) $\left.\left(\mathrm{NO}_{3}\right)\right\}$ n $74($ Figure 4), and $\left\{\left[\mathrm{Cu}(1,2\right.\right.$-bis(4-pyridyl)ethylene) $\left.\mathrm{Cl}] \cdot 2 \mathrm{H}_{2} \mathrm{O}\right\} \mathrm{n} 75$ (Figure 5) having different dimensionality and network topology and a mixed-valent porous $\mathrm{CuI} / \mathrm{CuII}$ framework, $\left[\mathrm{Cu}^{\mathrm{II}} \mathrm{Cu}_{2}^{\mathrm{I}}(2,4\right.$-pyridinedicarboxylate $\left.\left.) 3\right] \cdot 2 \mathrm{H}_{2} \mathrm{O}\right\} \mathrm{n} 76$ has also been isolated using suitable linkers 2,4-pyridinedicarboxylate and pyrazine by controlling $\mathrm{Cu}(\mathrm{II})$ and dihydroxyfumaric acid 1 stoichiometry.

\section{Conclusions.}

The aim of this review was to give an overview of the data about the occurrence of dihydroxyfumaric acid 1 in biological sources and its synthetic transformations into target products. We concentrated on reactions that relate to a single product. Methods are chosen for their novelty and we only discuss very significant developments and improvements regarding dihydroxyfumaric acid 1 . The products derived from dihydroxyfumaric acid 1 can be successfully used to make other materials, but we feel that they will find greater application in the future, hence their position in the review.

\section{References}

[1]. Fenton, H. J. H., J. Chem. Soc. 1894, 65, 899-911.

[2]. Fenton, H. J. H., Brit. Assoc. Advance Sci. Rep. 1895, 663-671.

[3]. Fenton, H. J. H.; Wilks, W. A., J. Chem. Soc. 1912, 101, 1570-1582.

[4]. Hartree, E. F., J. Am. Chem. Soc. 1953, 75(12), 6244-6249.

[5]. Souchay, P.; Fleury, D.; Fleury, M., C. R. Acad. Sc. Paris 1967, 264, C, 2130-2133.

[6]. Neuberg, C.; Schwenk, E., Biochem. J. 1915, 71, 104-113.

[7]. Banga, I.; Szent-Gyorgyi, A., Z. Physiol. Chem. 1938, 266, 58-63.

[8]. Banga, I.; Philippot, E., Z. Physiol. Chem. 1939, 268,147-152.

[9]. Duca, Gh., PhD Thesis, SUM, Chisinau,1979.

[10]. Stafford, H. A.; Magaldi, A.; Vennesland, B., Science 1954, 120, 265-266.

[11]. Stepanow, A.; Kusin, A., Ber. Dtsch. Chem. Ges. 1934, 67, 723-726.

[12]. Fukunaga, K., J. of Biochem. 1960, 47(6), 741-744.

[13]. Rodopulo, A. K. Bases of winemaking biochemistry (in Russian), Light and food industry Publ., Moscow, 1983.

[14]. Сычев, А. Я., Дука, Г. Г. Виноделие и виноградарство МССР,1985, 12, р. 38.

[15]. Gonta, M., Dr.Sc. Thesis, SUM, Chisinau, 2008.

[16]. Gonta, M., Analele ştiințifice ale USM, Seria „Ştiinţte chimico-biologice”, Chişinău, 2006. p. 71

[17]. Porubin, D.; Hecht, S.; Li, ZZ.; Gonta, M.; Stepanov, I., J. Agric. Food. Chem. 2007, 55 (17), $7199-204$.

[18]. Hartree, E. F., J. Am. Chem. Soc. 1953, 75, 6244-6249.

[19]. Goodwin, S.; Witkop, B., J. Am. Chem. Soc. 1954, 76, 5599-5603.

[20]. Secară, N.; Duca, Gh.; Macaev, F., The International Conference dedicated to the $50^{\text {th }}$ anniversary from the foundation of the Institute of Chemistry of the Academy of Science of Moldova”. 2009, p. 213.

[21]. Secară, N.; Duca, Gh.; Macaev, F., Chem. J. Moldova 2010, 5 (2), 59-67.

[22]. Yalpani, M.; Wilke, G., Chem. Ber. 1985, 118, 661-669.

[23]. Kemp, D. S.; Bowen, B. R.; Muendel, C. C., J. Org. Chem. 1990, 55, 4650-4657.

[24]. Day, A.; Arnold, P. P.; Blanch, R. J.; Snushall, B. J., Org. Chem. 2001, 66, 8094.

[25]. Buschmann, H. J.; Jansen, K.; Schollmeyer, E., Thermochim. Acta 2000, 346, 33-36.

[26]. El Houaj, M.; Young, H. K.; Luhmer, M.; Kim, K.; Bartik, K., J. Chem. Soc., Perkin Trans. 2. 2001, $2104-2107$.

[27]. El Houaj, M.; Luhmer, M.; Ko, Y.; Kim, K.; Bartik, K., J. Chem. Soc., Perkin Trans. 2. 2001, 804-807.

[28]. Marques, C.; Nau, W. M., Angew. Chem. Int. Ed. 2001, 40, 3155-3160.

[29]. Wagner, B. D.; Fitzpatrick, S. J.; Gill, M. A.; MacRae, A. I.; Stojanovic, N., Can. J. Chem. 2001, 79, 11011104.

[30]. Mock, W. L.; Shih, N. Y., J. Am. Chem. Soc. 1988, 110, 4706-4710.

[31]. Mock, W. L.; Shih, N. Y., J. Org. Chem. 1986, 51, 4440-4446.

[32]. Mock, W. L.; Shih, N. Y., J. Org. Chem. 1983, 48, 3619-3619.

[33]. Tuncel, D., Steinke, J. H. G., Chem Commun. 2002, 496-497.

[34]. Mock, W. L.; Irra, T. A.; Wepsiec, J. P.; Manimaran, T. L., J. Org. Chem. 1989, 54, 5302-5308.

[35]. Lee, J. W.; Ko, Y. H.; Park, S. H.; Yamaguchi, K.; Kim, K., Angew. Chem. Int. Ed. 2001, 40, 746-749.

[36]. Lee, E.; Kim, J.; Heo, J.; Whang, D.; Kim, K., Angew. Chem. Int. Ed. 2001, 40, 399-402.

[37]. Whang, D.; Park, K. M.; Heo, J.; Ashton, P.; Kim, K.; J. Am. Chem. Soc. 1998, 120, 4899-4900.

[38]. Jun, S. I., Lee; J. W., Sakamoto, S.; Yamagushi, K.; Kim, K., Tetrahedron Lett. 2001, 41, 471-475.

[39]. Mock, W. L.; Pierpont, J., J. Chem. Soc., Chem. Commun. 1990, 1509-1511. 
[40]. Isobe, H.; Tomita, N.; Lee, J. W.; Kim, H. J.; Kim, K.; Nakamura, E., Angew. Chem. Int. Ed. 2000, 39, 42574260.

[41]. Jeon, Y. M.; Whang D.; Kim K., J. Am. Chem. Soc. 1996, 118, 9790-9791.

[42]. Burnett, C. A.; Lagona, J.; Wu, A.; Shaw, J. A.; Coady, D.; Fettinger, J. C.; Day, A. I.; Isaacs, L., Tetrahedron 2003, 59, 1961-1970.

[43]. Haido, T.; Rudkevich, D. M.; Redek, J. Jr., J. Am. Chem. Soc. 1999, 121, 11253-11254.

[44]. Yin, G.; Wang, Z.; Chen, Y.; Wu, A.; Pan, Y., Synlett. 2006, 1, 49-52.

[45]. Kang, J.; Kim, J., Tetrahedron Lett. 2005, 46, 1759.

[46]. She, N.; Gao, M.; Cao, L.; Yin, G.; Wu, A., Synlett. 2007, 16, 2533-2536.

[47]. Zheng, L. M.; Zhang, Y. Q.; Zeng, J. P.; Qiu, Y.; Yu, D. H.; Xue, S. F.; Zhu, Q. J., Tao Z. Molecules, 2008, 13, 2814-2822.

[48]. Kunsagi-Mate, S.; Szabo, K.; Lemi, B.; Bitter, I.; Nady, G., Kollar. Thermochim. Acta. 2005, 425, $121-126$.

[49]. Saki, N.; Akkaya, E. U., J. Inclusion Phenom. Macrocycl. Chem. 2005, 53, 269-273.

[50]. Klaerner, F. G.; Kahlert, B., Acc. Chem. Res. 2003, 36, 919-932.

[51]. Buvari-Bareza, A.; Rak, E.; Meszaros, A.; Barcza, L., J. Inclusion Phenom. Macrocycl. Chem. 1998, 32, 453459.

[52]. Zimmerman, S. C., Top. Curr. Chem. 1993, 165, 71-102.

[53]. She, N.; Gao, M.; Wu, A.; Isaacs, L., Org. Lett. 2009, 11 (12), 2603-2606.

[54]. Takahashi, S.; Kuroyama, Y.; Sonogashi, Y.; Hagihara, N., Synthesis 1980, 627-630.

[55]. Taki, M.; Wolford, J. L.; O'Halloran, T. V., J. Am. Chem. Soc. 2004, 126, 712-713.

[56]. Maruyama, S.; Kikuchi, K.; Hirano, T.; Urano, Y.; Nagano, T., J. Am. Chem. Soc. 2002, 124, 10650-10651.

[57]. Meng, X. M.; Zhu, M.Z.; Liu, L.; Guo, Q.X., Tetrahedron Lett. 2006, 47, 1559-1562.

[58]. Gong, H. Y.; Zheng, Q. Y.; Zhang, X. H.; Wang, D. X.; Wana, M. X., Org. Lett. 2006, 8, 4895-4898.

[59]. Xiang, Y.; Tong, A. J.; Jin, P. Y.; Ju, Y., Org. Lett. 2006, 8, 2863-2866.

[60]. Martinez, R.; Zapata, F.; Caballero, A.; Espinosa, A.; Tarraga, A.; Molina, P., Org. Lett. 2006, 8, 3235-3238

[61]. Xu, Z. C.; Xiao, Y.; Qian, X. H.; Cui, J. N.; Cui, D. W.; Org. Lett. 2005, 7, 889-892.

[62]. Wang, J. B.; Qian, X. H., Org. Lett. 2006, 8, 3721-3724.

[63]. Guo, X. F.; Jia, L. H., J. Am. Chem. Soc. 2004, 126, 2272-2273.

[64]. Nolan, E. M.; Lippard, S. J., J. Am. Chem. Soc. 2003, 125, 14270-14271.

[65]. Chen, Q. Y.; Chen, C. F., Tetrahedron Lett. 2005, 46, 165-168

[66]. Metiver, R.; Leray, I.; Valeur, B., Chem. Commun. 2003, 996-997.

[67]. Deo, S.; Godwin, H. A., J. Am. Chem. Soc. 2000, 122, 174-175.

[68]. Liu, J. M.; Bu, J. H.; Zheng, Q. Y.; Chen, C. F.; Huang, Z. T., Tetrahedron Lett. 2006, 47, 1905-1908.

[69]. Xiang, Y.; Tong, A., J. Org. Lett. 2006, 8, 1549-1552.

[70]. Tumambac, G. E.; Rosencrance, C. M.; Wolf, C., Tetrahedron 2004, 60, 11293-11297.

[71]. Liu, J. M.; Zheng, Q. Y.; Yang, J. L.; Chen, C. F.; Huang, Z.T., Tetrahedron Lett. 2002, 43, 9209-9212.

[72]. Bricks, J. L.; Kovalchuk, A.; Triefinger, C.; Nofz, M.; Buschel, M.; Tolmachev, A. I.; Daub, J.; Rurack, K., J. Am. Chem. Soc. 2005, 127, 13522-13529.

[73]. Vallee, B. L.; Auld, D. S. In Methods in protein Sequence Analysis. Jornvall H., Hoog J.O., Gustavsson A.M.Eds. Brikhauser, Basel. 1991.

[74]. Hu, S. L.; She, N. F.; Yin, G. D.; Guo, H. Z.; Wu, A. X.; Yang, C. L., Tetrahedron Lett. 2007, 48, $1591-1594$.

[75]. Lagona, J.; Fettinger, J. C.; Issaacs, L., Org. Lett. 2003, 5, 3745-3747.

[76]. Abrahams, B. F.; Hudson, T. A.; Robson, R., J. Am. Chem. Soc. 2004, 126, 18624-8625.

[77]. Abrahams, B. F.; Hudson, T. A.; Robson, R., J. Chem. Eur. J. 2006, 12, 7095-7099.

[78]. Abrahams, B. F.; Hudson, T. A.; Robson, R., J. Mol. Struct. 2006, 796, 2-8.

[79]. Gandhi, B.A.; Green, O.; Burstyn, J.N. Inorg. Chem. 2007, 46, 3816-3820.

[80]. Masaoka, S.; Akiyama, G.; Horike, S.; Kitagawa, S.; Ida, T.; Endo, K. J. Am. Chem. Soc. 2003, 125, 11521153.

[81]. Mohapatra, S.; Maji T. K., Dalton Trans. 2010, 39, 3412-3419. 